MATEC Web of Conferences 46, 05003 (2016)

DOI: $10.1051 /$ matecconf $/ 20164605003$

(C) Owned by the authors, published by EDP Sciences, 2016

\title{
Fire protection concepts for Timber-Glass Composite façades
}

\author{
Andreas Schleicher \\ Vienna University of Technology Vienna, Austria
}

\begin{abstract}
The issues of this article are subject of the research project "Timber-Glass Composite Façades | Behavior in Case of Fire | Fire Protection Concepts" which is performed by Brandrat ZT GmbH in cooperation with the Department of Architectural Sciences and Timber Engineering, Vienna University of Technology.

It is part of the research program "Urban Solutions 2014" and is funded by the Vienna Business Agency. Start of the project took place in October 2014 and it should be completed in March 2017. The project management is carried out by the author of this paper.
\end{abstract}

The main objectives can be summarized as follows: Growth and densification in urban areas require the development of intelligent and resource-efficient building systems for "Smart Cities" of the future. By using timber-glass composites (TGC) the primary energy demand of buildings can be reduced substantially. This research project examines the feasibility of applications of this new technology in multi-story and high-rise buildings.

Critical aspects concerning fire protection such as flammability of timber elements, fire spread and failure of façade elements with bracing capacity will be analyzed. Different strategies will be developed in case studies and validated by structural analysis. Large scale mock ups of TGC façade elements will be checked on their suitability in fire tests.

The findings of this research will lead to innovative fire safety concepts for building systems with TGC façades. Compliance with the high safety standards for multi-story buildings in urban areas like Vienna is one of the main objectives of this work. The adaptation of these fire safety concepts to the national standards of the neighboring countries will be continued subsequently. The gained knowledge should lead to further cooperation with companies for serial productions with TGC technology.

\section{INTRODUCTION}

\subsection{Basic principles}

The specific design feature of TGC elements is a continuous adhesive bonding between the glass pane and an adapter frame made of timber. Approved serial applications are using bond lines made of silicone adhesives - however, current research projects are also investigating alternative adhesives with increased stiffness (e.g. polyurethane, acrylate, epoxy adhesives). The connection between the glazing and the adapter frame enables TGC façades to serve as a structural element especially for horizontal forces like wind or earthquake loads. Thereby other bracing elements like walls or crossings in the façade level can

This is an Open Access article distributed under the terms of the Creative Commons Attribution License 2.0, which permits unrestricted use, distribution, and reproduction in any medium, provided the original work is properly cited. 

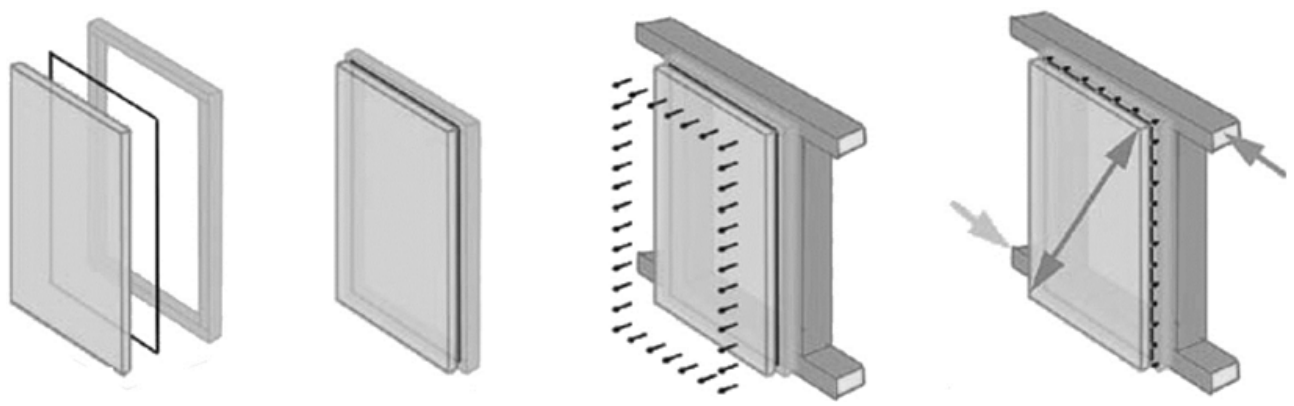

Figure 1. Schematic illustration of the basic principles of TGC façade elements. Picture credits: Winter, W., Tragende Holz-Glas-Klebeverbindungen, Grundlagen und Anwendungsmöglichkeiten, 5. Europäischer Kongress für effizientes Bauen mit Holz, 2012.

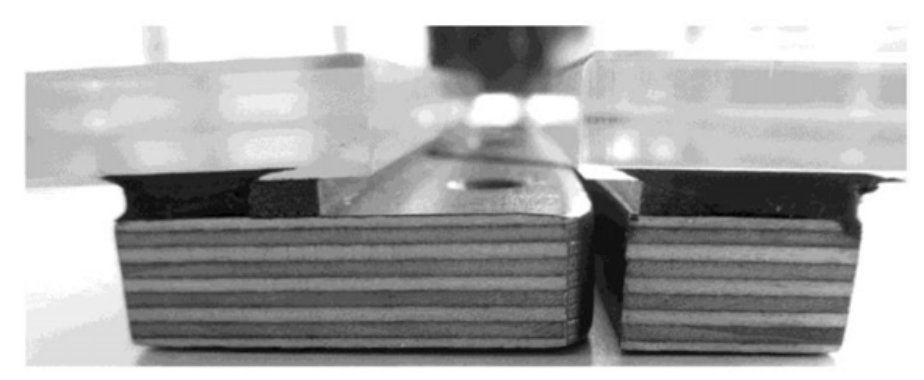

Figure 2. TGC system with flat adapter frame (shear). Picture credits: Uniglass Handbuch für die Planung und Erstellung von Uniglass | Facade Holz-Glas-Verbundelementen, 2014.

be reduced, depending on the main structure of the building. The basic principles of TGC elements can be described as follows and are depicted in Fig. 1.

- adhesive bonding of glass pane and adapter frame

- mounting of the composite element to a substructure

- force-locked connection of façade with floor slabs

- horizontal load transfer by TGC element.

Higher load capacities can be achieved by load transmission by shear (adhesive bond line) in combination with contact by blocking the glass pane. Additional blocking forces are concentrated in the corners between the adapter frame and the glazing and lead to higher stiffness with less deformation. Modeling and calculation of these structural elements with both shear forces in the bond line and a compression diagonal in the glass pane were subject of research projects and dissertations by the Department of Architectural Sciences and Timber Engineering, Vienna University of Technology [1, 2]. In figure 2 and 3 the different details of a TGC system with a flat adapter frame (shear) and a TGC system with a u-shaped adapter frame (shear and contact) are illustrated.

\subsection{Motivation for TGC-applications in multi-story buildings}

Small scale applications of TGC for windows and conservatories are already used by the building industry. Pilot projects of two-story family houses represent the current state of the art. Hence TGC 


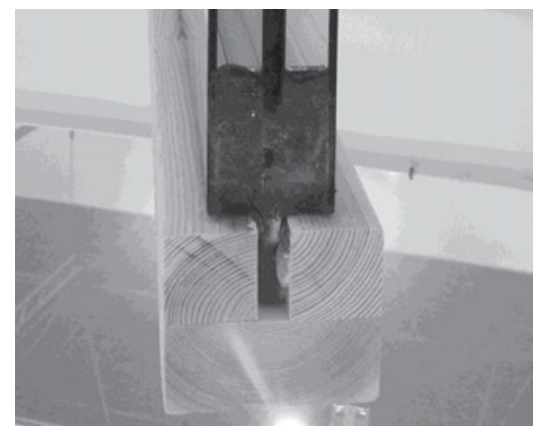

Figure 3. TGC system with U-shaped frame (shear and blocking contact). Picture credits: author (Glasstec 2014 Düsseldorf).

façades should also be spread to applications in larger buildings due to the positive aspects of this technology listed below:

- transparent architecture with façade systems without visible bracing elements

- double use of glazing as a climate shell and as a structural element

- solar energy gains through transparency without thermal bridges

- sustainability, reduced primary energy consumption and recyclability.

\subsection{Specific risks concerning fire protection issues and TGC façades}

In order to implement TGC applications in multi-story and high-rise buildings, both European and national laws, standards and guidelines must be considered as an assessment basis. The European Regulation No. 305/2011 [3] gives the following essential requirements for the limitation of fire risks:

"The construction works must be designed and built in such a way, that in the event of an outbreak of fire

- the load bearing resistance of the construction can be assumed for a specified period of time,

- the generation and spread of fire and smoke within the works are limited,

- the spread of fire to neighboring construction works is limited,

- the occupants can leave the works or can be rescued by other means,

- the safety of rescue teams is taken into consideration".

On the national level the "Richtlinien des Österreichischen Instituts für Bautechnik (OIB Richtlinien)" [4] provide the current state of the art concerning building technology and fire safety in Austria. Fire protection requirements concerning façades of multi-story buildings can be identified as follows:

- prevention of fire spread across the façade to the second floor level, located above the fire

- no danger to people and rescue teams by the falling of large façade parts

- prevention of spread of fire through gaps or joints and voids in the range of floor slabs.

Due to the specific design of TGC façades the following risks have to be considered and, where appropriate, additional measures have to be taken into account: 
- flammability of individual components of the façade system (timber substructure and adapter frame, adhesives)

- maintaining the same level of protection for high-rise buildings, while using combustible materials in the façade area

- failure of TGC façade elements with bracing capacity in case of fire.

\section{FIRE PROTECTION CONCEPTS FOR TGC-APPLICATIONS}

Fire safety regulations by the OIB Richtlinien [4] can be complied by TGC façades for objects up to building classification 5 (flight level up to $22 \mathrm{~m}$ ). Due to the increased level of security for buildings with a flight level of more than $22 \mathrm{~m}$ (high-rise buildings) the requirement, that only non-combustible material must be used, cannot be fulfilled with TGC façades, mainly because of components such as timber and adhesives. Any deviation from these requirements is only acceptable if the same level of protection can be demonstrated in conjunction with corresponding compensation measures (e.g. specific sprinkler systems). Depending on structure, usage and building classification one of the following three strategies might be used to develop object-specific fire protection concepts for buildings using TGC technology.

\subsection{Protection of TGC façades in case of fire}

In order to fulfil the requirement of preventing fire spread across the façade, the implementation of various fire protection measures into TGC façade systems is being investigated in this research. Basically fire resistant glazing could be used for TGC façades, however, due to economic considerations this is not a realistic solution. Besides the issue of how to protect the bonding in case of fire remains unsolved.

The design of TGC façades with fire resistant parapets seems to be more appropriate and can be solved either with façade-integrated fire-resistant panels or with parapets being part of the main structure of the building. Depending on the details of these measures it is possible to realize fire resistance between 30 and 120 minutes. With a height of at least $120 \mathrm{~cm}$, these elements meet the requirement of preventing vertical fire spread in accordance with the current OIB Richtlinien [4]. However, this measure is not designed to protect TGC façades against reduction or loss of bracing capacity in case of fire.

Another option to prevent horizontal and vertical fire spread across the façade is to use automatic sprinkler systems, especially when they are designed with the objective to prevent fire spread in the façade area. In this case no additional structural measures of the façade have to be taken into account. For high-rise buildings with a flight level of more than $22 \mathrm{~m}$ automatic sprinkler systems might also be considered as a compensatory measure for the use of combustible materials in TGC façades in some cases, depending on the type of façade and the sprinkler system. Besides in fire tests of façades in conjunction with sprinkler systems temperatures in the range of $200^{\circ} \mathrm{C}$ in the fire room were observed TGC façades with silicone adhesives will still serve as a bracing element (with reduced capacity) in this temperature range.

\subsection{Partial failure of TGC façades in case of fire}

When using TGC façades as structural bracing elements (e.g. in building structures without a core element for primary bracing) the bracing capacity of the façade has to be ensured in case of fire. The division into fire compartments or small cells by vertical components is more effective to retain the bracing capacity of the building structure (at least with reduced capacity) in case of fire. On the other hand building structures with fire compartments divided by floor slabs might not retain any bracing capacity due to the fact that in case of fire TGC elements will fail along all sides of the building in a worst case scenario. This would lead to a total failure of the bracing capacity of the building, even if 

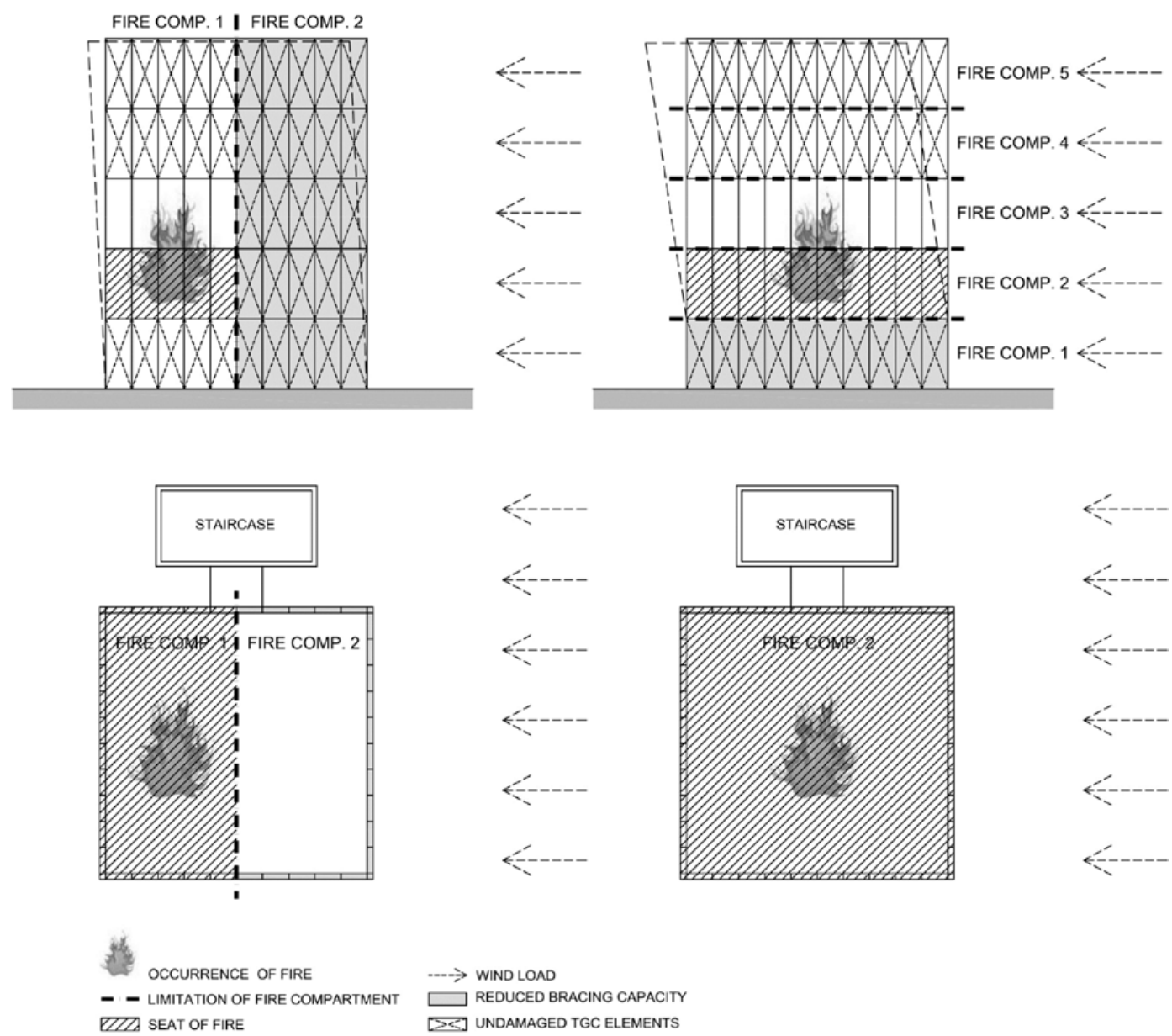

Figure 4. Schematic illustration of the relationship between the layout of fire compartments and the bracing capacity of the TGC façade. Picture credits: author.

the floor levels above the seat of fire would remain undamaged. The relation between the layout of fire compartments and the bracing function by TGC façade is depicted in Fig. 4.

\subsection{Total failure of TGC façades in case of fire}

TGC elements might be appropriate for building constructions with interior bracing core elements to absorb high horizontal forces of wind and earthquake loads and thereby relieve the core. Particularly in multi-story buildings with timber structures, which usually show higher elasticity and larger deformation compared to reinforced concrete structures, TGC façades can be used economically [1].

In the current research project various building structures consisting of a primary bracing by an internal core component with different stiffness (wood and wood-composite structures, reinforced concrete structures) and a secondary bracing by TGC façade elements are being investigated in case studies. The aim of this ongoing work is to evaluate the relationship between primary and secondary bracing and resulting optimizations. 


\section{MATEC Web of Conferences}

In case of fire bracing capacity of TGC façades could fail if the primary bracing by the inner core is designed with fire resistance corresponding to the building classification. The secondary bracing does not necessarily require a defined fire resistance due to the fact that fire is considered an accidental situation. Only those actions, whose occurrence in case of fire is likely to happen, have to be taken into account - a simultaneous occurrence of other accidental actions doesn't have to be considered [5].

In a structural analysis based on the partial factor method according to European standards Eurocode EN 1990 [6] leading and accompanying actions have to be considered for accidental design situations like fire. In this case the design value $\mathrm{E}_{\mathrm{d}}$ of the relevant effects of actions will be determined according to the following Eqs. (1) and (2).

$$
\mathrm{E}_{\mathrm{d}}=\mathrm{E}\left\{\mathrm{G}_{\mathrm{k}, \mathrm{j}} ; \mathrm{P} ; \mathrm{A}_{\mathrm{d}} ;\left(\psi_{1,1} \text { or } \psi_{2,1}\right) \mathrm{Q}_{\mathrm{k}, 1} ; \psi_{2, \mathrm{i}} \mathrm{Q}_{\mathrm{k}, \mathrm{i}}\right\} j \geq 1 ; i>1 .
$$

The combination of actions in brackets \{\} can be expressed as:



$E_{d} \quad$ Design value of effect of actions according to EN 1990

$G_{k, j} \quad$ Characteristic value of permanent action $j$

$P \quad$ Relevant representative value of a prestressing action

$A_{d} \quad$ Design value of an accidental action

$Q_{k, l} \quad$ Characteristic value of the leading variable action 1

$Q_{k, i} \quad$ Characteristic value of the accompanying variable action $i$

$\psi_{1} \quad$ Factor for frequent value of a variable action

$\psi_{2} \quad$ Factor for quasi-permanent value of a variable action.

In a structural analysis regarding accidental action of fire the variable actions (e.g. wind load) have to be considered either with the factor for quasi-permanent value or, if it is a leading variable action, with the factor for frequent value. These factors are specified by the national annexes to EN 1990 - in Austria these values are defined by $\psi_{2}=0$ (factor for quasi-permanent value) and $\psi_{1}=0,2$ (factor for frequent value) according to ÖNORM B 1990-1 [7]. Hence TGC elements do not need to fulfil any requirements to fire resistance, if these parameters are considered in the design and calculation of the building construction.

\section{TGC EXPERIMENTS UNDER TEMPERATURE STRESS}

To examine the behaviour of TGC elements when being exposed to different temperature loads a series of small scale timber-glass samples with different adhesives were tested at the beginning of the research project. The experiments were conducted in the laboratory of the Department for Building Construction and Technology of the Vienna University of Technology.

After reaching the targeted temperature load, the specimens were taken from the oven and put into a universal testing machine (Zwick, Type Z250) to perform an individual pressure test.

The selected types of adhesive for the tests are being used for serial TGC façades on the one hand and on the other hand examined in current research projects. Hence they constitute a representative choice in accordance with the current state of the art and science. Three series of specimens were produced with the following adhesives:

- Nolax C44.8505: two-component adhesive on EP basis

Component A: Silane Polymer formulated

Component B: Epoxy Resin formulated 


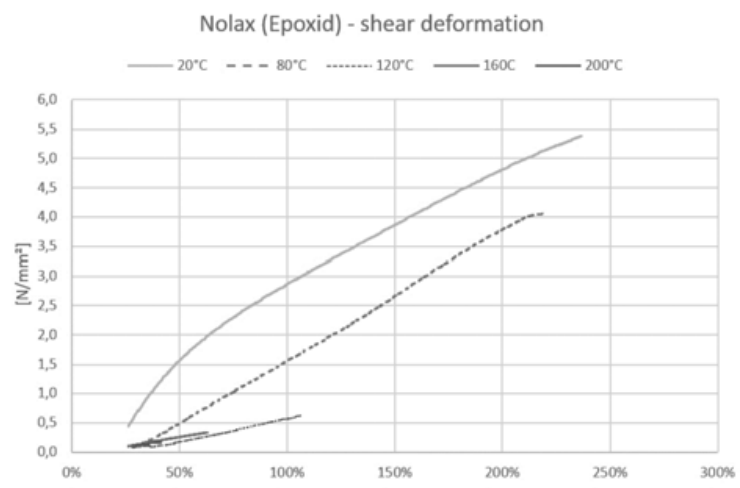

Figure 5. Graph of shear deformation of TGC specimens with Epoxy bond line. Picture credits: author.

- SikaFast-5221 NT: two-component adhesive based on acrylate Component A: SikaFast-5221 NT

Component B: SikaFast-5200

- Ottocoll S 660: two-component silicone adhesive on Alcoxy base.

The experiments were carried out under continuous loading rate at different temperature levels $\left(20^{\circ} \mathrm{C}\right.$, $80^{\circ} \mathrm{C}, 120^{\circ} \mathrm{C}, 160^{\circ} \mathrm{C}, 200^{\circ} \mathrm{C}$ ) until failure of the specimens. During the tests the following failure modes occurred:

- fracture in the bond line (cohesive failure)

- fracture between bond line and timber element (adhesive failure)

- fracture between bond line and glass element (adhesive failure)

- mixed fracture (cohesive and adhesive failure)

- fracture in the timber element.

The evaluation of the measured data shows, amongst others, significant changes in shear deformation under temperature stress. The reduction in shear strength substantially depends on the type of adhesive as shown in the following graphs. Specimens with epoxy bond line rapidly change their initial properties (Fig. 5) whereas samples with silicone bonding show a more constant behaviour but with significantly lower shear strength at the initial temperature of $20^{\circ} \mathrm{C}$ (Fig. 6).

\section{OUTLOOK TO FIRETESTS WITH TGC FAÇADE MOCK UPS}

In the current work package of the project a typology of different TGC façade systems will be designed and evaluated. Focus of the assessment is on one hand the compliance of fire safety regulations, on the other hand to increase the bracing capacity with respect to the intended applications in multi-story buildings. The following drawings offer an insight of the current status of the design process by means of a single and a double façade with TGC elements.

In the further progress of this research the following measures to increase the bracing capacity of the TGC elements will be evaluated:

- blocking of the glazing in the inner façade level

- timber-glass composites bonded with modified epoxy adhesives in the inner façade level

- timber-glass composites bonded with silicone adhesives in the outer façade level 


\section{MATEC Web of Conferences}

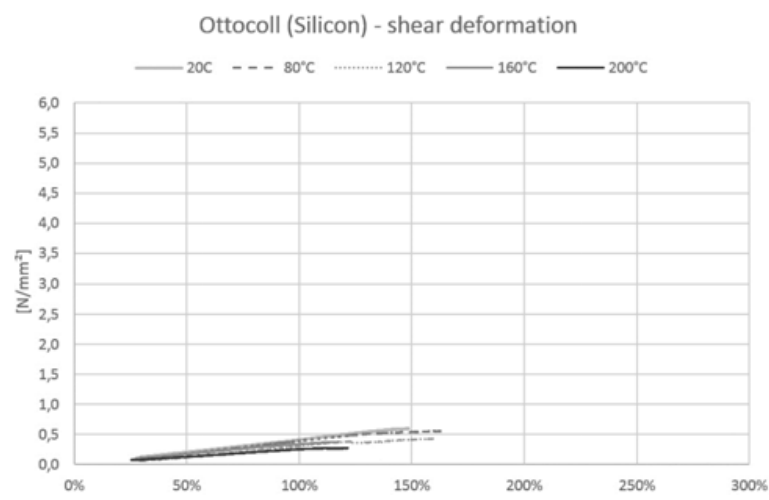

Figure 6. Graph of shear deformation of TGC specimens with Silicone bond line. Picture credits: author.



Figure 7. Schematic drawing of a single façade with TGC elements. Picture credits: author.

- framework made of veneer laminated timber products

- coupling of TGC elements to increase bracing capacity.

Verification of the fire safety requirements concerning TGC applications in multi-story buildings up to classification 5 and for buildings with a flight level above $22 \mathrm{~m}$ will be done on the basis of mock ups in fire tests. The following tests will be provided:

- testing according to ÖNORM B 3800-5 [8] or -6 [9] with respect to the criteria of fire spread across the façade and falling of large façade parts

- testing according to ÖNORM EN 13501-2 [10] to prove the criteria EW 30-ef.

\section{DISCUSSION}

The previously completed work packages of the research project "Timber-Glass Composite Façades | Behaviour in Case of Fire | Fire Protection Concepts" and the experimental series "Bonded 


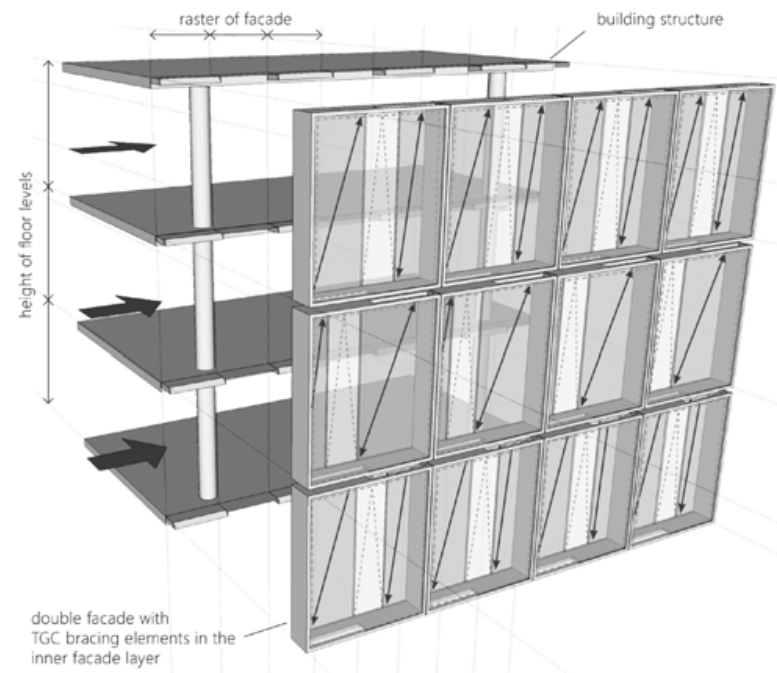

Figure 8. Schematic drawing of a double façade with TGC elements. Picture credits: author.

Timber-Glass Composites under Thermal Stress" lead to the following conclusions:

- TGC bond lines with the investigated epoxy or acrylic adhesives can absorb significantly higher shear stresses than silicon bond lines at room temperature.

- As temperature loads above $80^{\circ} \mathrm{C}$ are likely in the façade area even without exposure to fire, TGC applications with the investigated acrylic adhesive are not appropriate and will not be investigated furthermore in the course of this project.

- TGC applications using the investigated epoxy adhesives cannot record any significant shear strength under a temperature load that occur in case of fire and hence cannot serve for bracing in this case

- TGC applications with the examined silicone adhesive provide a very constant behavior up to a temperature load of $200{ }^{\circ} \mathrm{C}$ with little reduction of shear strength. Further research is needed to examine the behavior of TGC with silicone adhesives at higher temperature loads which occur on the façade area in case of fire.

- The strategy of "Protection of TGC façades in case of fire" seems to be appropriate only in conjunction with an automatic sprinkler system due to the significant reduction of shear strength of epoxy and acrylate adhesives at a temperature load of $200^{\circ} \mathrm{C}$.

The following interim results from the currently running work packages "Fire Scenarios and TGC Structures" and "TGC Façade Prototypes" are important for the further progress of the project:

- Structural analysis from current case studies of multi-story buildings with TGC façades show that a combination of reinforced concrete structures with an internal core element (primary bracing) and a TGC façade for secondary bracing offers very little reduction of the primary bracing due to the high stiffness of the reinforced concrete structure. A combination of structures made of wood or wood composite with TGC façades appear to be more advantageous due to the lower stiffness of these structures and will be investigated in the ongoing project.

- Double façade system using TGC elements have positive aspects in terms of their intended usage in multi-story buildings. The outer façade level might be used to protect the inner façade level both from climate conditions (e.g. rain, wind, sunlight) and from thermal effects by fire, when the design is appropriate. 


\section{MATEC Web of Conferences}

- Higher bracing capacity can be achieved by coupling of TGC façade elements into a multi-story TGC façade structure.

\section{References}

[1] Winter, W., "Application of Load Bearing Glass Timber Composites", $4^{\text {th }}$ Forum Wood Building Nordic, Växjö, 2015.

[2] Hochhauser, W., "Ein Beitrag zur Bemessung und Berechnung von geklebten und geklotzten Holz-Glas-Verbundscheiben”, Dissertation, 2011.

[3] Regulation (EU) No 305/2011 of the European Parliament and of the Council of $9^{\text {th }}$ March 2011 laying down harmonised conditions for the marketing of construction products and repealing Council Directive 89/106/EEC.

[4] Österreichisches Institut für Bautechnik (OIB), "Richtlinien des Österreichischen Instituts für Bautechnik", http://www . oib.or . at/de/oib-richtlinen, 2015.

[5] Hosser, D., Brandschutz in Europa - Bemessung nach Eurocodes, Erläuterungen und Anwendungen zu den Brandschutzteilen der Eurocodes 1 bis 5, Beuth Verlag GmbH, 2012.

[6] ÖNORM EN 1990:2003-03-01, "Eurocode - Grundlagen der Tragwerksplanung".

[7] ÖNORM B 1990-1:2013-01-01, "Eurocode - Grundlagen der Tragwerksplanung - Teil 1: Hochbau, Nationale Festlegungen zu ÖNORM EN 1990 und nationale Ergänzungen”.

[8] ÖNORM B 3800-5:2013-04-15, "Brandverhalten von Baustoffen und Bauteilen, Teil 5: Brandverhalten von Fassaden, Anforderungen, Prüfungen, Beurteilungen“.

[9] ÖNORM B 3800-6:2013-04-15, "Brandverhalten von Baustoffen und Bauteilen, Teil 6: Brandverhalten von Kasten-Doppelfassaden (2-schalige Fassade), Anforderungen, Prüfungen, Beurteilungen".

[10] ÖNORM EN 13501-2:2010-02-15, "Klassifizierung von Bauprodukten und Bauarten zu ihrem Brandverhalten, Teil 2: Klassifizierung mit den Ergebnissen aus den Feuerwiderstandsprüfungen, mit Ausnahme von Lüftungsanlagen". 